- Identifies apprenticeship as a controlling influence in the development of ethics in dentistry

in the nineteenth century.

- Indicates the comparative status of dentistry as a professional activity in the nineteenth

century.

- Draws attention to the indentures in the BDA museum.

\title{
Ethics; 'In consideration of the love he bears.' Apprenticeship in the nineteenth century, and the development of professional ethics in dentistry. Part 1. The practical reality
}

\author{
M. G. H. Bishop ${ }^{1}$ D. Gibbons ${ }^{2}$ and S. Gelbier ${ }^{3}$
}

\begin{abstract}
This paper takes a look at the ancient institution of apprenticeship. In doing so it regards the conventions of the scheme as having had a positive influence on the morality, legal identity, and professional allegiance of dentists during the ethical development of their profession in the nineteenth century. Two important effects can be detected from the records available. One is general, since the moral ground of apprenticeship derived from, and spread throughout, society, and the other is particular to the development of dentistry as a profession, as those who were apprenticed to dentists acquired a natural loyalty to their dentist Masters in person, and to their craft.
\end{abstract}

Apprenticeship (from the old French Apprentis) is the system by which a young person is bound to serve for a fixed term, originally seven years, in exchange for instruction in a craft. In his survey of six centuries of English Social History, ${ }^{1}$ G. M. Trevelyan shows how important the system was in creating the English mix of classes in early modern times, with the sons of country gentlemen apprenticed to the best shops in the City of London. He also makes the statement that with the growth of new industrial conditions at the end of the period he examines, apprenticeship disappeared. This, if true at all, did not apply to the surgeons and apothecaries to whom it might be thought the new profession of dentistry would look for their model. The

${ }^{1 *}$ General Dental Practitioner, Hertford; ${ }^{2}$ Professor \& Head of Division, ${ }^{3}$ Professor, Division of Dental Public Health and Oral Health Services Research, Guy's King's \& St Thomas' Dental Institute of King's College London

*Correspondence to: Malcolm Bishop, Queen Anne House, 2A St Andrew Street, Hertford, Hertfordshire SG14 1JA E-mail:dph.admin@kcl.ac.uk

\section{Refereed Paper}

Received 06.12.01; Accepted 22.04.02

๑ British Dental Journal 2002; 193: 261-266 statement would also be questioned by those doing a gentleman apprenticeship with the Great Western Railway, or solicitors doing their articles, both groups, the engineer and the men of law, being apprenticed well into the twentieth century. It has not been surprising to find evidence of dental apprenticeships extending over the whole nineteenth century.

From the beginning of the modern legal structure of the barber surgeons, records show that there was concern over what we would now call ethical behaviour in the management of apprentices by their masters, as well as the moral behaviour of those apprentices. This concern was aimed to ensure two things, that the physical well-being of the apprentice and that of the population was guarded. Abuse of the system by unscrupulous masters using their apprentices as cheap labour, and taking the premiums of their parents or guardians while having too many to teach, was prevented.

Sir Thomas More, as Chancellor, acted within the terms of a 1503 Act of Henry $\mathrm{VII}^{2}$ when supervising the setting up of the Ordinances of the Barber Surgeons of
London in $1530 .^{3}$ Amongst other things, these Ordinances required that apprentices must be healthy, so as not to put the King's liege people at risk, and that no Master might take on more than four at one time.

Lilian Lindsay in her informative essay 'The London Dentist in the Seventeenth Century"4 states of the Barber Surgeons Company that in the sixteen hundreds, 'The apprentice who was 10 to 12 years of age was bound for five to seven years - the indentures being drawn up by the beadle. There was a preliminary examination, for personal cleanliness, freedom from disease or deformity of body or mind, a knowledge of reading, writing and elementary knowledge of Latin:

Continuing education was mandatory for barber-surgeons in the early modern days, and after the young person finished his apprenticeship and became a journeyman (a position which might be compared with that of an associate GDP of today) or assistant he was expected to attend lectures. This stipulation in Sir Thomas More's Ordinances now seems exceptionally farsighted, a fore-runner five hundred years 


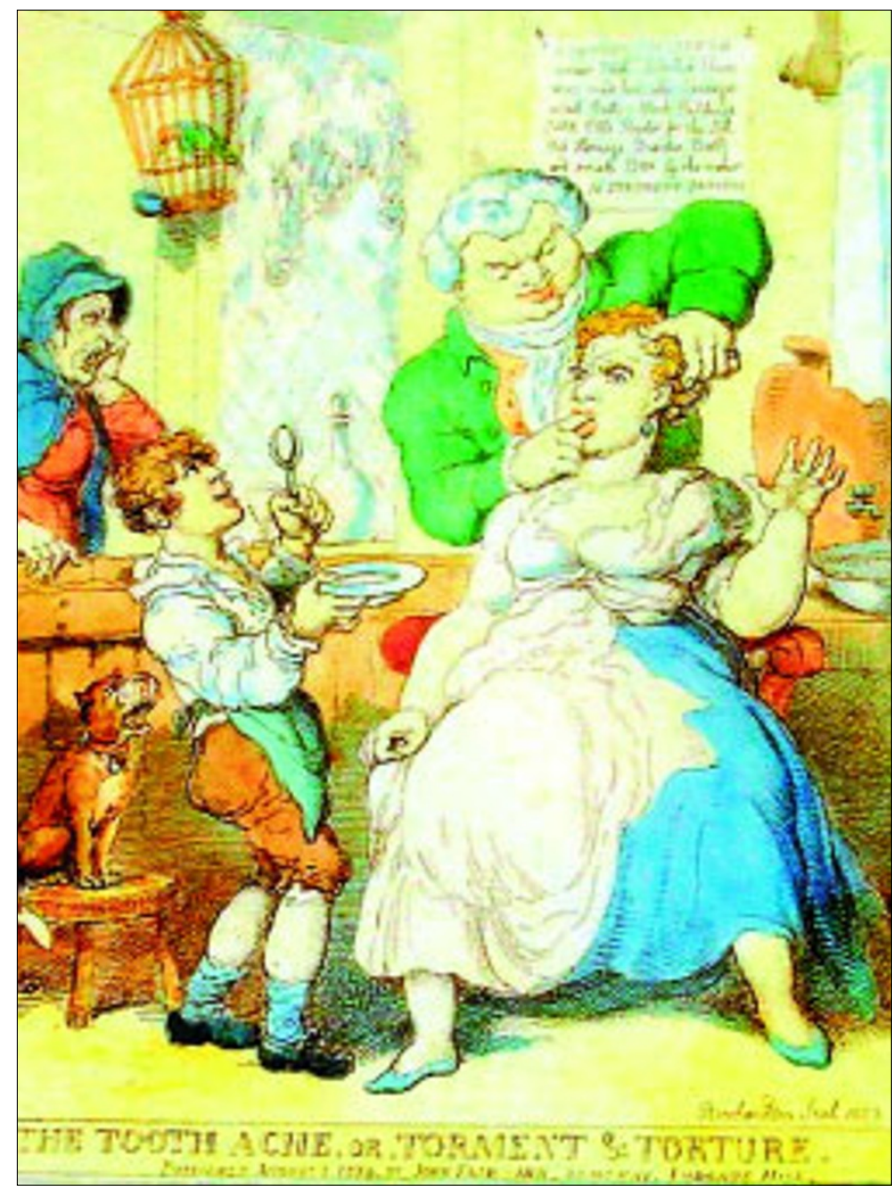

Fig. 1 1823. Thomas Rowlandson (1756-1827) The Toothache, or Torment \& Torture. As well as the young apprentice, the facilities for hand-washing should be noticed. The placard on the wall refers to Barnaby Factotum; Draws Teeth, Bleeds, shaves, wigs, sausages, wash balls, black puddings, Scotch pills, powder for the itch, herrings and beer. The Latin tag means roughly 'Up for anything' $25 \times 19.5 \mathrm{~cm}$. By kind permission, Christopher King Esq.

ago of today's insistence on continuing professional development.

In earlier times, where young men did apprentice themselves, it was possibly not with toothdrawing primarily in mind, but to a master who followed the calling as a sideline. The young apprentice could then develop a natural talent. Hillam notes the apprenticeship of Moses Burch to William Norman of Stepney perruke maker and operator of teeth in 1720, when the term of apprenticeship was seven years. Anne Hargreaves in her book 'White as Whales Bone: Dental Services in Early Modern England ${ }^{5}$ gives other examples of eighteenth century references that involve dentistry as a subsidiary activity to surgeon, apothecary, or barber. ${ }^{6}$

Agabus Molden, the son of a barbersurgeon, was inrolled as a barber in Norwich in 1713, but in his advertisements he refers to himself only as Operator for the Teeth. The process of apprenticeship was not necessarily all plain sailing, and on the $25^{\text {th }}$ February in 1732, Thomas Platfoot, one of the three apprentices known to have been articled at various times to Molden, ran away at the age of $19 .{ }^{7}$ Trevelyan, while acknowledging that abuse of apprentices did occur, concludes that overall the effect was beneficial. ${ }^{8}$ Molden himself seems more concerned about abuse in the other direction, with the possibility of his runaway apprentice going to work for a rival; 'Any Person that shall entertain or detain the said Apprentice from his aforesaid Master's Service, will be prosecuted as the Law in such Cases directs.'

Little changed in apprenticeships from 1530 to 1800 , except that the age of the apprentice increased slightly. The 1823 Rowlandson illustration used here shows how young the apprentice could look, (Fig. 1) and in a caricature sketch of 1796, (Fig. 2) Gillray makes Canning the height of a young teenager as he assists Fox in 'Curing John Bull of his Canine Appetite.' ${ }^{9}$

State Taxation on apprenticeships, which continued until 1811, and which imposed a close control on the nature and title of trades followed by apprentices, is a disappointing source of record on dentistry up to that date. One possible reason for this is that the terminology was inflexible. This would perpetuate the inrolment of 'dental' apprentices under other titles, barber or apothecary, for example. Anne Hargreaves puts forward another plausible explanation in the interesting view that operators for the teeth favoured limiting their training to a single successor, where not leaving their skill to a family member. ${ }^{10}$ Stamp duty on indentures continued at varying rates throughout the nineteenth century, ensuring that, as it were, the State kept its finger on the pulse, but identification by trade was lost.

The researcher needs to look elsewhere for evidence of the influence of apprenticeship, and is fortunate to find it, thanks to the hard work of Alfred Hill in the nineteenth century, ${ }^{11}$ and of Dame Lilian Lindsay, ${ }^{12}$ J. Menzies Campbell, ${ }^{13}$ Ronald Cohen, Christine Hillam, ${ }^{14}$ and Anne Hargreaves, ${ }^{15}$ in the twentieth century. All of these help. For example, details of the apprenticeship and pupillage histories of several of the most notable and influential dental figures of the nineteenth century were given by Lilian Lindsay in 1955. This set of 27 personal profiles of major figures from the nineteenth century, Personalities of the Past, was published in the BDJ. The $\mathrm{PhD}$ thesis of Christine Hillam ${ }^{16}$ adds to this the necessary contrast of the ordinary dental practitioner in the provinces, and she estimated that nearly half of the providers of dental services had been trained by apprenticeships between 1800 and 1850.

Finally the BDA museum has in its archive eleven dental indentures from a wide geographical and social spread of apprenticeships contracted in the later nineteenth and early twentieth centuries.

\section{THE INDENTURES}

The documents which have survived in the archives of the British Dental Association, although too few to allow for conclusions to be drawn about how representative they are of dental apprenticeship in general, cover a wide range of transactions and locations. They are, like the ephemera which have formed the basis of the previous papers looking at the ethics of the profession, both collectively and individually fascinating. There is an indenture for a dentist chemist from $1860,{ }^{17}$ and another of great interest is the indenture for Leslie James Godden 'an infant of the age of 18 years' who was apprenticed to Cecil Hastings Bradnam in $1915^{18}$ for two years as a Mechanical Dentist (Fig. 3).

A century before this, the purely mechanical branch of dentistry was sought out by the surgeons, like John Tomes, who wished to commence in dentistry. In this case though, what is more probable is evi- 


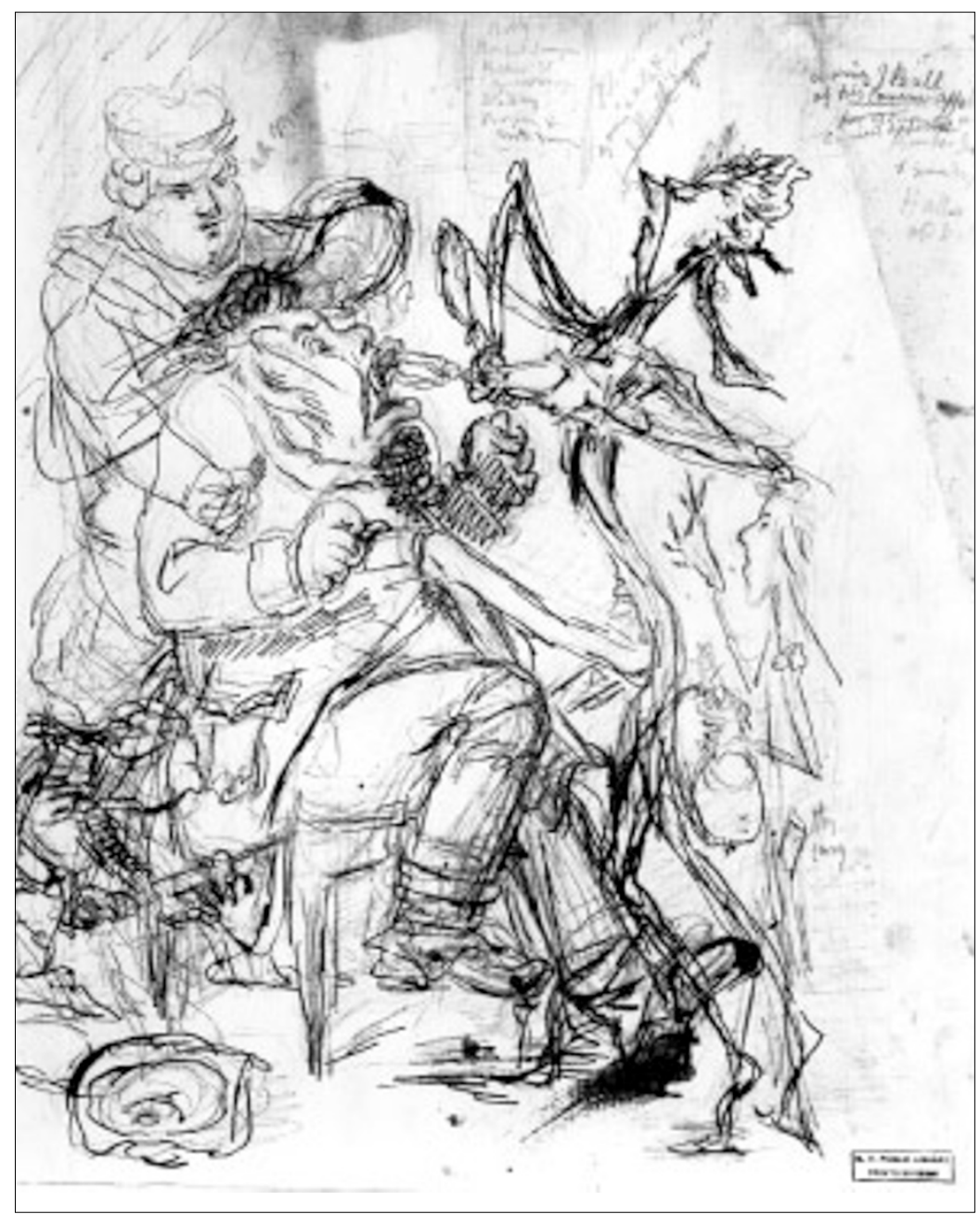

Fig. 2 c.1796. James Gillray (1757-1815) Curing John Bull of his Canine Appetite. This preparatory sketch in ink and pencil for a caricature not subsequently produced, shows Pitt, assisted by a sketchy Canning as his apprentice, operating on 'John Bull'. The head supporter is not identified, but his 'modern' technique is of interest. Print Collection, Miriam and Ira D. Wallach Division of Art, Prints and Photographs, The New York Public Library, Astor, Lenox and Tilden Foundations. By kind permission, $33.4 \mathrm{~cm} \times 26.8 \mathrm{~cm}$

dence of a dental technician being trained. The premium paid was £20.00.

Technicians' apprenticeships persisted long after those for dentists ceased, and on the 1st of January 1940, 25 years on from Godden's apprenticeship, William (Bill) Welsh was apprenticed to Bert Walker, Dental Technician, of St Peter's Place Brighton. ${ }^{19}$ He received 2/6d a week in his first year, 5/- in his second year, rising to 10/- in his fourth and final year. Bill Welsh retired from the Royal Dental Hospital when it closed in 1985.

Premiums paid varied greatly, and from another indenture, one of the two which show a family connection, comes something most affectingly human, the title to this paper; 'in consideration of the love he bears', for this is the premium 'paid' on 26th December 1876 when 'Henry Reginald Fryer Brooks of the town of Banbury in the County of Oxford ... put himself Apprentice to Robert Heygate Brooks of the said Town of Banbury in the said County of Oxford, Surgeon Dentist to learn his Art ... after the
Manner of an Apprentice. ${ }^{20}$ (Fig. 4) It is a reminder that the Victorians were not, as so often portrayed by politically motivated commentators, devoid of human feeling. Not that they were silly, for the premium is completed with: :....and the services to be rendered by him: The other family indenture, ${ }^{21}$ that of 'Lewin Lewis Rose Mosely of No 21 Cornwallis Gardens - Hastings in the County of Sussex ... to Benjamin Lewin Mosely of Number 236 Robertson Street Hastings in the said County of Sussex Dentist' in 1892, required no financial premium, but lacks any romantic insert.

\section{THE PRACTICAL REALITY}

An invaluable insight into how the dental apprenticeship system worked in practice in the first half of the nineteenth century, is not an Indenture, but the account given by A. J. Woodhouse to the Annual Meeting of the British Dental Association in August 1896 and printed as an Original Communication in the Journal. ${ }^{22}$ His Master, Thomas Sheffield, is identified by Christine Hillam as having been in practice in Exeter from 1831 onwards, in 1842 having rooms in Palace Gate.

'My acquaintance with the profession commenced in 1842, at which time there was no means of acquiring a knowledge of it but by apprenticeship to a dentist. I had the good fortune to be placed with Mr. Thomas Sheffield of Exeter, who was in the fore-front of the best practitioners of his day.... My articles bound me to Mr. Sheffield for four years, in them he undertook to teach me "the art, mystery, and professional employment of a dentist," and I promised "to serve him faithfully and keep his secrets."

The mode of instructing me that Mr. Sheffield adopted was to work with me at the bench and occasionally to take me into his surgery, where I saw him operate. I was also at his side when he saw the gratis patients who came to him each morning at nine o'clock to be relieved of pain. I did all his mechanical work during my apprenticeship, and after about three months he gave the care of the gratis patients into my hands, and I well remember when I went down alone to extract my first tooth, which I am happy to say I accomplished successfully. From that time I selected from among the cleanest of these poor people those who needed teeth stopped, and attended to them. Mr. Sheffield used to examine the teeth when I had prepared them, and afterwards when the filling was completed, but he soon left me to my own devices, except when any great difficulty arose, when he always came to my help. After about a year or so, he left me in charge of his private patients when he went for his holiday.

Among the dentists of those days there were a very few who were members of the Royal College of Surgeons. A great proportion of those who practised had no professional education and indeed, many, little education of any kind.

Then all dentists jealously guarded their modes of practice, few knew other members of the profession, for each worked as a hermit in his cell, and allowed no one out of his house to know any detail of his work. It was a common thing to hear a man say "he would give anything to know how So-and-so stopped with gold," for other men's work would occasionally be seen in a patient's mouth. ${ }^{23}$

Jealous guarding was written into the indentures of each apprentice, and whistleblowing was also specifically included, with the requirement that the Master be informed 


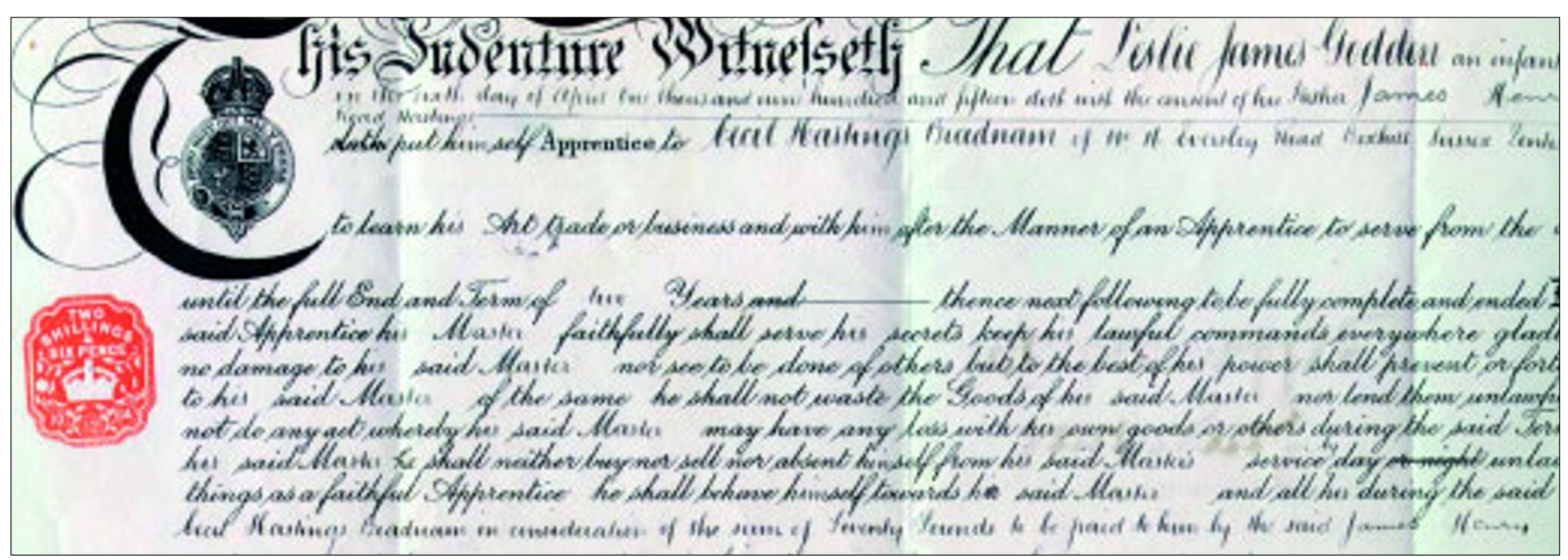

Fig. 3 1915. The indenture of Leslie James Godden. An Infant of 18 years. LDBDA 06.10. By kind permission of the British Dental Association

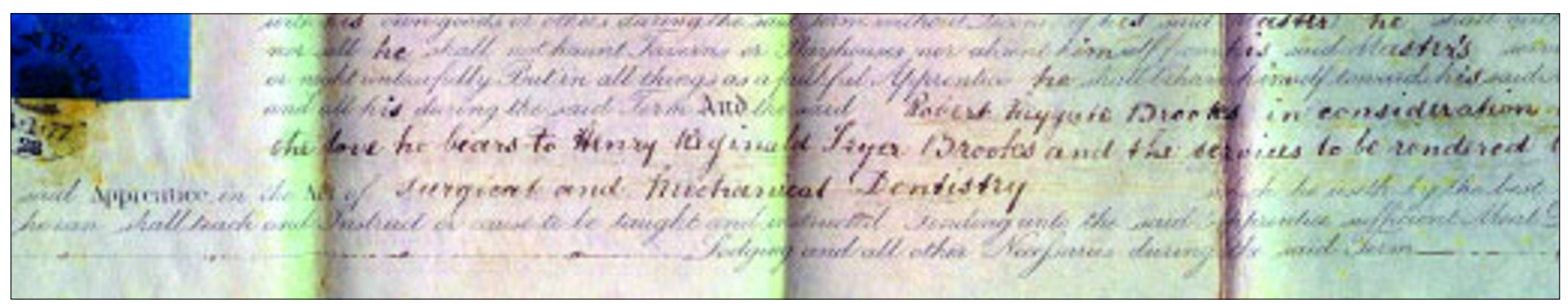

Fig. 4 1876. Detail from the indenture of Henry Reginald Fryer Brooks to Robert Heygate Brooks, showing the premium as being 'In consideration of the love he bears' LDBDA 06.7 By kind permission of the British Dental Association

of any attempt to damage his affairs. This contentious subject has an ancient history in the defence of trade. The last paragraph of Woodhouse's account serves also as a reminder that Adam Smith (1723-1790), the Scottish political economist who wrote The Wealth of Nations, was no friend of the institution of apprenticeship, criticising it on just these grounds as tending to stagnation, and as being inefficient and unjust. A critique has recently been published by Emma Rothschild. ${ }^{24}$ That the institution could be inefficient and unjust, since there was no uniformity of training, and only those who could afford it were bound to the best Masters, was true, but it is not the quality of training which is the concern of the paper, but the moral conditions of an apprenticeship. Also, as Woodhouse showed in another part of his address, and as this paper shows, apprenticeship led to an esprit de corps and corporate identity which stimulated a very real advance before it yielded to other training methods.

\section{MORALS}

In the seventeenth century, individual professional morality and ethical concern for the well-being of patients can be seen in the writing of Charles Allen in 1685, ${ }^{25}$ while in the eighteenth century the various operators for the teeth illustrated in the paper published in this journal ${ }^{26}$ would have had to demonstrate a level of 'professionalism' acceptable to the population in which they lived and worked, where everyone knew everyone else. By the nineteenth century though, the numbers of those caring for the teeth built up enough for more to be considered than the sense of individual professional responsibility which those in previous centuries possessed.

The invaluable and scrupulous work of the late Christine Hillam, already mentioned, on the development of Provincial Dentistry from the late eighteenth century to 1855 illustrates numerically and geographically the explosion of activity outside London. Until the 1830s the number of true dentists in the provinces did not exceed 100 at any one time, ${ }^{27}$ but by the mid 1850s, the total number of practitioners including the London dentists, stood at the figure of $1,500 .{ }^{28}$ By 1879 as a consequence of the rush to register after the 1878 Act there were over $5,000^{29}$ and forty years later than that, in 1921 when the Dentists Act was being debated, the astonishing number of well over 10,000 was accepted as including both qualified and unqualified personnel. ${ }^{30}$ It is as a result of this numerical increase that it becomes realistic to look for the moral, as well as the legal, determinants of the ethics of dentists as an identifiable group.

The intended general influence of apprenticeship on the morals of young den- tists, rather than the particular benefit of being an apprentice to the profession of dentistry, is demonstrated in this composite transcript of the 'moral' components from two BDA indentures. To the base of an 1868 indenture $^{31}$ (Fig. 5) have been added relevant parts from a later 1876 example. ${ }^{32}$

\section{This indenture witnesseth that} Herbert Arthur Laurence son of William Laurence now residing at Jersey, and of Cheltenham doth bind himself Apprentice ..., unto Henry John Andrews of the said Island of Jersey, after the Manner of an Apprentice to serve him from the day of the date hereof for and during the full term of four years next ensuing, ..... During all which time he the said Apprentice his said Master shall and will faithfully serve, his secrets keep, his lawful commands everywhere gladly obey, and diligently and carefully demean and behave himself towards him. He shall not do, or willingly suffer to be done by others, any hurt, prejudice or damage to the ... affairs of his said Master, ... but the same to the utmost of his power shall hinder or thereofforthwith warn. He shall not commit fornication, [or adultery 1876] nor contract Matrimony within the said term. At cards, dice, tables, [or bowls 1876] or any other unlawful game, he shall not 
play, whereby his said Master may be damaged, or lose any of his own or other's goods, during the said term .... He shall not absent himself by day or night [at any time 1876] from his said Master's service, without his leave, on pain of making up every day he absented himself, at the expiration of the said term. He shall not haunt ale houses, taverns, play houses, or any other places of debauchery; but in all things behave himself, during the said term, as a good and faithful Apprentice ought to do; [and behave himself towards his said Master and all his family as well in words as in Deeds. 1876] The said H A Laurence agrees to be indoors every evening by Ten O'Clock

On the other side of the agreement, it was arranged that the apprentice should be taught the Art and Profession of Mechanical and Surgical Dentist and be provided with food, lodging, and washing by his master. The premium paid by his father to $\mathrm{Mr}$ Andrews was forty pounds in four annual instalments. The apprentice Herbert Laurence was to be given as pocket money one shilling a week for his first year and two shillings a week for his second year. This rose to four shillings per week for his fourth and last year. Pocket money is the actual term used in the indenture, and in view of the earlier prohibitions one wonders what he was going to be allowed to spend it on. That the prohibitions needed to be made at all implies a level of riotous enjoyment of life by $14-$ to 20 -year-olds in the past that almost excites envy in these sober times.

Within the basic format the apprenticeship document was flexible, and each of the BDA documents is different. The printed forms allow not only for Apprentices of either gender, but for Mistress or Master to be inserted. The Master or Mistress did not have to instruct personally, and the proforma given in 1902 by the Encyclopaedia of Forms and Precedents ${ }^{33}$ for apprenticing surgeons or vets, equally applicable by then to dentists, incorporated the following passage to allow for the legal requirements of training 'off site':

(d) That he will permit the apprentice during the last two years of the said term to walk resort to and attend

days in every week or oftener if

requisite the hospital of ___ at__ or any other hospital or hospitals or medical school or place of lectures upon medicine or surgery and midwifery or other subjects necessary or proper for his better instruction in the profession of a surgeon.

Other more social changes are to be seen, for example section (b) in the pro forma above takes note of the status of an apprentice surgeon, in that the master: ...will provide for the apprentice good and sufficient meat and drink and lodging befitting the station in life of the apprentice.' In the 1887 Articles of Apprenticeship of $\mathrm{Mr}$ J.B. Parfitt to A Pallant Esq, ${ }^{34}$ a Memorandum addition states; 'That it was arranged that the Pupil should have a fortnights holiday every year'. The same document alters the hours of compulsory attendance earlier prevailing from day and night to the more agreeable; 'He shall not .... absent himself from his said Masters service during business hours (that is to say between the hours

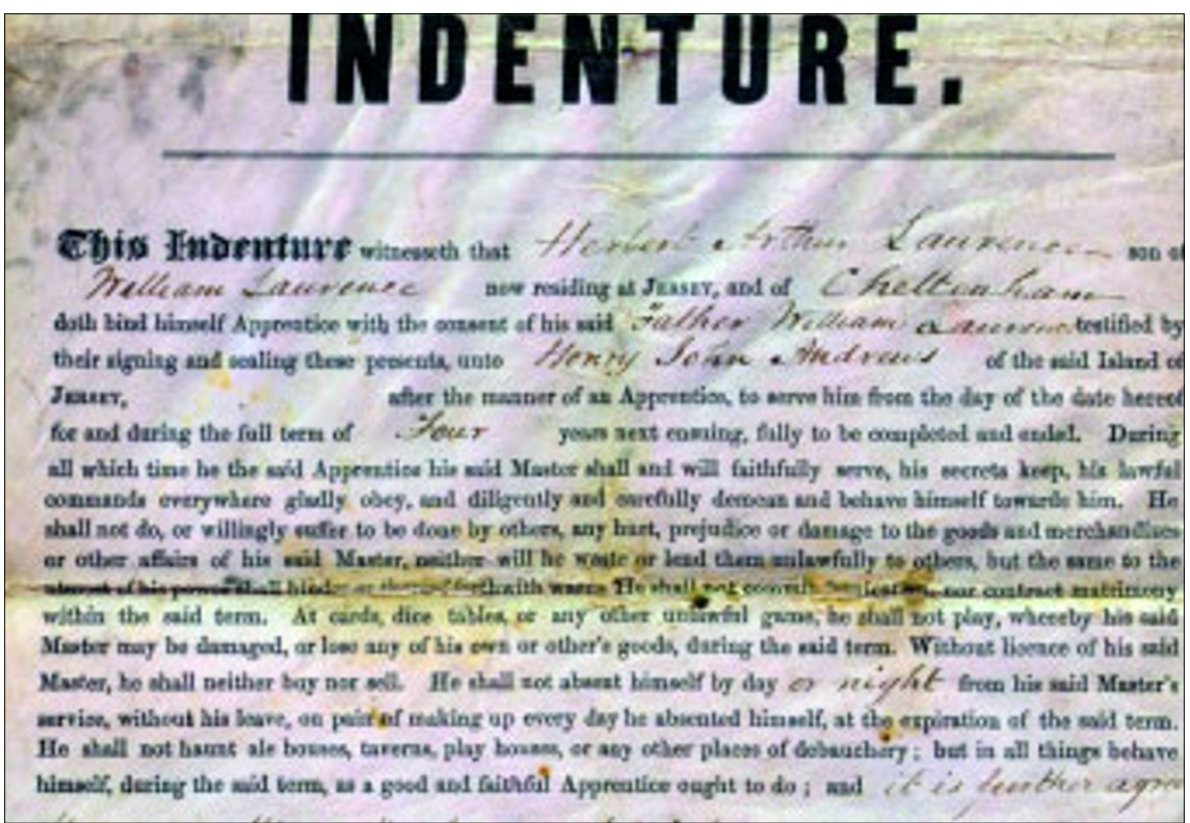

Fig. 5 1868. Detail of the indenture for Herbert Arthur Lawrence, showing the moral requirements demanded of an apprentice. LDBDA 06.1. By kind permission of the British Dental Association of eleven am and four thirty pm) unlawfully'. However, in Aberdeen where he was apprenticed to the Murison brothers in 1885, the hours for Alexander Reid were from 8 am to $6 \mathrm{pm}$, with one hour for dinner and on Saturdays from 8 am to $1 \mathrm{pm}^{35}$ (as an aside, the distances some of these young people travelled to be apprenticed are inexplicable with the data available, Reid appears to take the prize, coming to Aberdeen apparently from Gravesend).

One modification at least reflects professional rather than social ethical behaviour, and perhaps explains why some apprentices moved far from their home turf. Mr Pallant did not use a standard form, though the wording was similar, and the beautifully written copperplate document included an agreement that his pupil would "not at or after the expiration or other sooner determination of the said term in anyway advertise or use in any public announcement whatever the name of the said Arthur Pallant on behalf of any business to be carried on by the said Pupil nor practise the profession of a Dental Surgeon within eight miles of Maidenhead.'

\section{CROSS FERTILISATION}

The BDA documents include three indentures the particular interest of which is their suggestion of equivalence of professional aspiration. First, in the earliest indenture in the museum, ${ }^{36}$ we see in 1847 (Fig. 6) the son of a dentist apprenticed to a surgeon-apothecary. Frederick Hart Jones '(a Minor) of his own free will and by and with the consent and approbation of his Father John Jones of the Borough of Cambridge in the County of Cambridge SurgeonDentist doth put himself Apprentice to Robert Ransom of the said Borough of Cambridge Surgeon and Apothecary to learn his Art with him' Second, the apprenticeship of Arthur Alexander, the son of an accountant, to Alfred Matthews, Surgeon Dentist, ${ }^{37}$ has already been noted for its possible romance, but here it is the professional link which is notable, between: 'William Alexander of Liverpool in the County of Lancaster Accountant of the first part Arthur Alexander of Bradford in the County of York son of the said William Alexander of the second part and Alfred Marston Matthews of Bradford aforesaid Surgeon Dentist of the third part.'

Last, in $1887,{ }^{38}$ the son of a Gentleman (at the time meaning not the lowest order of chivalry, but a man of independent means) was put apprentice to a dentist when 'John Brodribb Parfitt of Vellore College Road in the Borough of Reading in the County of Berks (hereinafter called the said pupil) Son of Felix Brodribb Parfitt of the same place Gentleman of his own free will and accord and by and with the consent and 


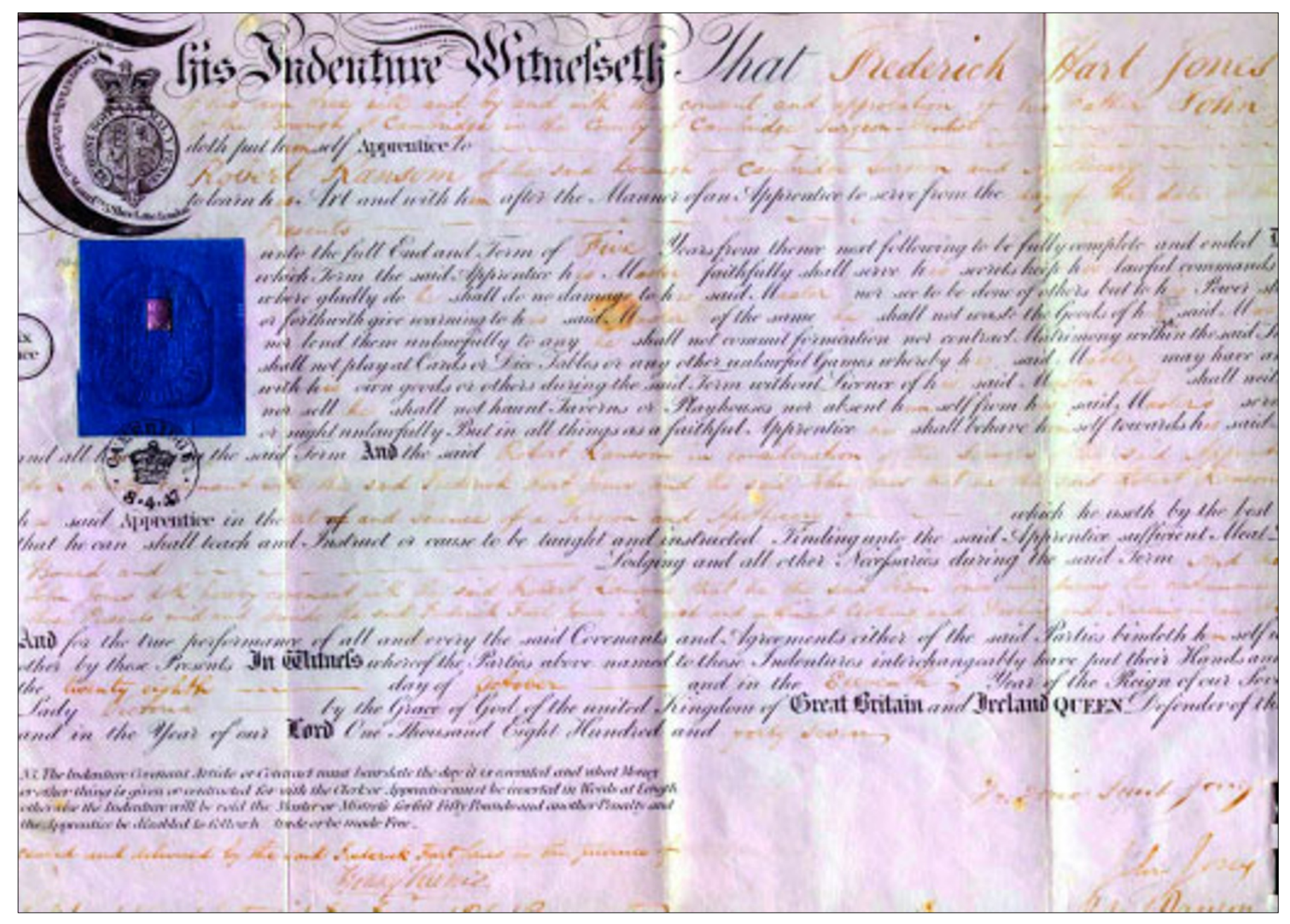

Fig. 6 1847. The earliest indenture in the BDA collection, for Frederick Hart Jones. LDBDA 06.3. By kind permission of the British Dental Association

approbation of his father testified by his executing these presents ... put himself Pupil to Arthur Pallant of Maidenhead in the said County of Berks Dental Surgeon.'

It is not appropriate to do more than draw attention to these indentures as examples, for it seems likely that the BDA collection was made and selected for documents of particular interest, and these three may have survived for that reason. They are nevertheless instructive in showing how the apprenticeship scheme allowed movement into and between the professions, and showing quite clearly how the dental profession was seen in the nineteenth century.

This first part of the paper has examined and illustrated the particular advantages of the Apprenticeship scheme to dentistry. In the next part, the general effect of apprenticeship on the ethics and morals of young people is detailed, and the twentieth century legacy outlined.

The assistance of the Curator of the BDA museum, Roxanne Fea, and of the Librarians in the Information Centre is most gratefully acknowledged.

1 Trevelyan G M. English Social History. A Survey of Six Centuries; Chaucer to Queen Victoria. London: Longman's, Green and Co Ltd, 1944 \& several later editions.
219 Henry VII C 7 'For making of Statutes by Bodies incorporate.' Statutes at large.

Sir Thomas More's Ordinances Appendix B. In Young S Annals of the Barber Surgeons London; Blades, East \&t Blades. 1890, pp579-586.

4 Lindsay L. The London Dentist of the Seventeenth Century. BrDent J 1946; 80: 76

5 Hargreaves AS. White as Whales Bone:Dental Services in Early Modern England. Leeds: Northern Universities Press, 1998.

6 Hargreaves op. cit. p.155-156.

7 Cubitt D. Two early eighteenth century dental advertisements from Norwich. Dental Historian 1992; 23: 5 .

8 Trevelyan G M. English Social History. A Survey of Six Centuries; Chaucer to Queen Victoria. London: Longman's, Green and Co Ltd, 1965 edn. pp321-322.

9 Print Collection, Miriam and Ira D. Wallach Division of Art, Prints and Photographs, The New York Public Library, Astor, Lenox and Tilden Foundations.

10 Hargreaves A S. White as Whales Bone:Dental Services in Early Modern England. Leeds: Northern Universities Press, 1998. pp128,129,138.

11 Hill A. The History of the Reform Movement in the Dental Profession in Great Britain During the last Twenty Years. London: Trübner \& Co, 1877.

12 Lindsay L. The London Dentist of the Seventeenth Century. Br Dent J 1946; 80: 75-80. Personalities of the Past No.1. BrDent J 1955; 98: 28-29.

13 Menzies Campbell J. From a Trade to a Profession. Byways in Dental History. 1958. Private edition.

14 Hillam C F. Brass Plate and Brazen Impudence. Dental Practice in the Provinces 1755-1855. Liverpool: Liverpool University Press, 1991.

15 Hargreaves A S. White as Whales Bone:Dental Services in Early Modern England. Leeds: Northern Universities Press, 1998.

16 Hillam C F. The development of Dental Practice in the Provinces from the late 18th century to 1855 . PhD thesis. Liverpool: University of Liverpool, 1986.

17 Indenture LDBDA 06.9 in the BDA Archive.

18 Indenture LDBDA 06.10 in the BDA Archive.

19 Clowser N. The Dental Technician. 2001; 54: 10.

20 Indenture LDBDA 06.7 in the BDA Archive.

21 Indenture LDBDA 06.2 in the BDA Archive.

22 J.Br.Dent.Assoc. 1897; 18: 21-30.

23 Woodhouse A J. Reminiscences of Fifty-four years in the Dental Profession. J BrDentAssoc 1897; 18: 23.

24 Rothschild E. Economic sentiments:Adam Smith Condorcet and the Enlightenment. Harvard, 2001.

25 Allen C. The operator for the Teeth. York, 1685.

26 Bishop M, Gelbier S, Gibbons D. Ethics - dentistry and toothdrawing in the late eighteenth and early nineteenth centuries in England. Evidence of provision at all levels of society. Br DentJ 2001; 191 : 575-580.

27 Hillam C F. The development of Dental Practice in the Provinces from the late 18th century to 1855. PhD thesis. , Liverpool: University of Liverpool, 1986. p.iv.

28 The Memorialist's letter written in 1857 to the Royal College of Surgeons. In Hill A Reform in the Dental Profession. London: Trübner \& Co, 1877.

29 Blandy H. Dental Advertising and the Dentists Act. London: John Bale \& Sons, 1893, p10.

30 Seddon J A. In Standing Committee B Dentists Bill. Official Report. Br Dent J 1921; 42: p564.

31 Indenture LDBDA 06.1 in the BDA Archive.

32 Indenture LDBDA 06.4 in the BDA Archive.

33 Encyclopaedia of Forms and Precedents, 1st ed. (1902-9); Butterworths. Vol.II 1902 Professional Apprenticeship. Precedent 21.

34 Indenture LDBDA 06.6 in the BDA Archive.

35 Indenture LDBDA 06.8 in the BDA Archive.

36 Indenture LDBDA 06.3, in the BDA Archive.

37 Indenture LDBDA 06.4 in the BDA Archive

38 Indenture LDBDA 06.6 in the BDA Archive. 